\title{
COVID-19 Küresel Salgınının Yaşı Bireyler Bağlamında Değerlendirilmesi
}

\section{Evaluation of the COVID-19 Global Epidemic in the Context of the Elderly Individuals}

\author{
Merve Ayşe Şahin ${ }^{1}$ (iD \\ ${ }^{1}$ Tokat Gaziosmanpaşa Üniversitesi Reşadiye Meslek Yüksekokulu, Sağlık Bakım Hizmetleri Bölümü, Yaşlı Bakım Programı, Tokat, TÜRKIYE
}

Geliş tarihi/ Date of receipt: 22/05/2020

Kabul tarihi/ Date of acceptance: 31/01/2021

(c) Ordu University Faculty of Health Sciences, Department of Nursing, Turkey, Published online: 18/04/2021

öz

Bulaşıcı hastalıkların ortaya çıktığı dönemlerde tüm insanlar fiziksel, sosyal, ruhsal, ekonomik ve kültürel olarak etkilenmektedir. Hastalığın tam olarak bilinememesi, tedavi ve bakım konusunda belirsizlikler yaşanması, durumu daha da ciddileştirmektedir. Yeni (Novel) COVID-19 virüsü, ilk kez Çin'in Hubei eyaletinin Wuhan şehrinde 2019 yılı Aralık ayında ortaya çıkmıştır. Çin'de başlayan bu salgın hızlıca birçok ülkeye yayılmış ve Dünya Sağlık Örgütü tarafindan da 11 Mart 2020'de pandemi olarak ilan edilmiştir.

Yetişkin bireylerde gözlenen non-spesifik belirtiler ateş, öksürük, halsizlik gibi üst solunum yolu hastalıklarına ait belirtiler olup, tablo ağırlaştıkça pnömoni, ağır solunum yetmezliği tarzında bulgular gelişmektedir. Çocuklarda bulgular genellikle asemptomatik veya çok hafif düzeyde bir üst solunum yolu enfeksiyonu şeklinde ortaya çıkmasına rağmen yetişkin ve özellikle de yaşlı bireylerde daha ağır bulgularla hastalık kendini göstermektedir. Çocuklarda pnömoni olgusu nadir görülürken yaşlılarda çoğunlukla rastlanan ve mortaliteye neden olan en önemli bir semptomdur.

Yaşın ilerlemesiyle ortaya çıkan fizyoljik, psikolojik ve sosyal değişimler, yaşlının bir kronik hastalığının ya da komorbid hastalıklarının olması, çoklu ilaç kullanımı gibi durumlar, yaşlıları bu hastalığa daha yatkın hale getirmektedir. Görüldüğü gibi bu hastalığın yaşlılarda ağır semptomlara ve fataliteye neden olması gerekçesiyle yaşlılarda tedbirlerin daha dikkatli ve emin adımlarla alınması gerekmektedir. Hastalıktan korunmada el hijyeni, damlacık ve sosyal izolasyon önlemleri önemlidir. Bu önlemlerin dikkatli ve aksatılmadan uygulanmasının pandemiyi azaltacağı umulmaktadır. COVID-19 virüsünün yaşlı bireyleri daha çok etkilemesi ve yaşlılarda ölümle sonuçlanan bir virüs olması nedeniyle, bu süreçte yaşlı bireyler virüsle mücadele konusunda önemli bir konuma sahip hale gelmiştir.

Anahtar Kelimeler: COVID-19, virüs, pandemi, salgın, yaşlı

\section{ABSTRACT}

In the period when infectious diseases occur, all people are physically, socially, spiritually, economically and culturally affected. The fact that the disease is not fully known, and the uncertainties about treatment and care make the situation more serious. The COVID19 virus first appeared in Wuhan, China's Hubei province, in December 2019. This epidemic that started in China spread rapidly to many countries and was declared as a pandemic by the World Health Organization on March 11, 2020. Non-specific symptoms observed in adult individuals are symptoms of upper respiratory diseases such as fever, cough, and weakness, and symptoms develop in the form of pneumonia and severe respiratory failure as the condition becomes serious. Although the findings usually appear as an asymptomatic or very mild upper respiratory tract infection in children, the disease manifests with more severe findings in adults and especially elderly individuals. While pneumonia is rare in children, it is the most common symptom that causes mortality in the elderly. Physiological, psychological and social changes that occur with the advancement of age, the presence of a chronic disease or co morbid diseases of the elderly, and multiple drug use make the elderly more prone to this disease. As can be seen, precautions should be taken with more careful and confident steps in the elderly, as this disease causes severe symptoms and fatality in the elderly. Hand hygiene, droplet and social isolation measures are important in preventing disease. Careful and uninterrupted implementation of these measures is expected to reduce pandemics. Because the COVID-19 virus affects older individuals more and is a death-causing virus in the elderly, older individuals have gained an important position in the fight against the virus in this process.

Keywords: COVID-19, virus, pandemic, epidemic, elderly

ORCID IDs of the authors: MAȘ: 0000-0003-3169-2911

Sorumlu yazar/Corresponding author: Öğr. Gör. Merve Ayșe ŞAHIN

Tokat Gaziosmanpaşa Üniversitesi, Reşadiye Meslek Yüksekokulu, Sağlık Bakım Hizmetleri Bölümü, Yaşlı Bakım Programı, Tokat, TÜRKIYE e-posta/e-mail: merve.keskin@ gop.edu.tr

Atıf/Citation: Şahin MA. (2021). COVID-19 küresel salgınının yaşlı bireyler bağlamında değerlendirilmesi. Ordu Üniversitesi Hemşirelik Çalışmaları Dergisi, 4(1), 96-104. DOI:10.38108/ouhcd.741640 


\section{Giriș}

COVID-19 virüsü adıyla tanımlanan SARSCoV-2 kaynaklı Yeni Tip Koronavirüs, Aralık 2019 sonlarında Çin'in Wuhan kentinde ortaya çıkmış olup, başta Avrupa olmak üzere kısa sürede Dünya'nın birçok ülkesinde etkili olmuştur. Zarflı bir RNA virüs olan COVID-19; SARS-CoV ve MERS-CoV gibi korana virüs ailesinden olup, virüsün ciddi solunum yetmezliği oluşturduğu bilinmektedir (TÜBA 2020). Dünya Sağlık Örgütü (DSÖ) 10 Ocak 2020'de ise 2019-nCoV adiyla bir rehber yayınlayarak ülkelerin önlem alması gerektiğini duyurmuştur (Dünya Sağlık Örgütü (WHO 2020a).

Dünya Sağl1k Örgütü tarafından COVID-19'un bir pandemi olduğu 11 Mart 2020 tarihinde ilan edilmiş olup (WHO 2020b), COVID-19'un çok önemli ve çok acil kontrol altına alınması gereken bir halk sağlığı sorunu olduğu bildirilmiştir (WHO 2020c). COVID-19 korona virüslerin sebep olduğu ilk pandemi olarak tarihe geçmiştir. Türkiye Cumhuriyeti Sağlık Bakanlığı tarafindan da 11 Mart 2020 tarihinde Türkiye'de de ilk vaka olgusuna rastlandığı belirtilmiştir. Hastalık hakkında yeterli bilgiye sahip olunmadığı için hastalığın tedavisinde ve salgının yayılımının kontrol altında alınmasında zorluklar yaşanmış, bu nedenle hastalık hızlıca yayılmıştır.

\section{COVID-19 İle İlgili Genel Bilgiler}

Hastalığa neden olan etken tam anlamıyla tespit edilmemiş olup, araştırmalar devam etmekte ve var olan söylemler kaynağın Çin'in Wuhan kentindeki Deniz Ürünleri Pazarında yasaya uygun olmayan yöntemlerle satılan hayvanların olduğuna işaret etmektedir (T.C Sağlık Bakanlığı Halk Sağlığ1 Genel Müdürlüğü 2020a). Hastalığın kaynağı ile ilgili belirsizlikler yaşansa da hastalığın ne şekilde bulaştığının bilinmesi, hastalıktan korunma ve alınması gereken önlemlerin belirlenmesinin önemini ortaya çıkarmaktadır.

Olguların Çin'de başladığı düşünüldüğünde virüsün inkübasyon süresinin diğer bir ifade ile hastalık belirtilerinin ortaya çıkması için gereken sürenin, ortalama 5-6 gün ya da minimum 2 günmaksimum 14 gün olduğu görülmüștür. Bulaştırıcılık süresi ile ilgili kesin bir bilgi olmamakla birlikte, kişiden kişiye bulaşın, belirtiler başlamadan 1-2 gün önce başladığı, belirtilerin kaybolmasıyla bulaştırıcılığın sonlandığ düşünülmektedir (Til 2020). COVID-19 enfeksiyonu için kanıtlanmış bir antiviral ilaç tedavisi yoktur (T.C Sağlık Bakanlığg Rehberi Halk Sağllğı Genel Müdürlüğü 2020b; WHO, 2020d). Bu nedenden ötürü tedavi semptomlara yönelik olarak yapilmaktadır.

$\mathrm{Bu}$ çalışmada yeni bir halk sağllğı sorunu olan COVID-19 ile ilgili genel bilgiler, COVID-19'un bulaşma yolları, belirtileri, korunma yolları, tedavisi, bakımı ve yaşlılar üzerindeki etkileri açıklanmaktadır.

\subsection{COVID-19 Virüsünün Bulaşma Yolları}

Bulaş yolu çoğunlukla enfekte insandan sağlam başka bir insana solunum yoluyla şeklindedir. Fakat korona virüs ile enfekte olmuş kişiler sadece inkübasyon döneminde değil aynı zamanda asemptomatik dönemde diğer bir ifade ile hastalık belirtileri göstermeyen kişiler yoluyla da bulaştırıcı olabilirler (Rothe ve ark., 2020). COVID-19 virüsü insandan insana damlackk ve temas yoluyla bulaştığından, bulaşma yoluna yönelik olarak alınması gereken en önemli önlemin ellerin en az 20 saniye olacak şekilde su ve sabun kullanılarak sık sık yıkanmasıdır (T.C Sağlık Bakanlığı Halk Sağlığ Genel Müdürlüğü 2020a).

Elde bulunan, virüslerin öldürülmesinde çok etkili bir yol olan (WHO 2020e) ve bulaşma yolu dikkate alındığında başka insanlarla yakın temasta bulunulduğunda virüsün yayılımını engelleyen bir yöntem olan el yıkamak, çok önemli olup; su ve sabun yokluğunda da yani diğer bir ifade ile ellerin yıkanamadığı durumlarda da \%60-70'lik alkol içeriği olan dezenfektanların kullanılabileceği de önerilmektedir (CDS 2020a; CDS 2020b). Sadece el hijyenine dikkat etmek yeterli olmayı ellerin yüz, göz, ağız, burun ya da başka bir vücut bölgesine dokunulmamasına da dikkat edilmelidir. Bulaş riski olan yerlere girme mecburiyetinde kalındığında eldiven takmak yeterli bir önlem olmayıp; aksine eldiven takarken hissedilen rahatlığın etkisiyle yüze ve vücuda dokunulması hastalığın bulaşmasına sebebiyet verebilir. Halka açık alanlarda eldiven kullanımı bireylerde el yıkama sıklı̆gının azalmasına ve hijyen algısının ortaya çıkmasına sebebiyet verip bireylerin ruh sağlığını da olumsuz etkileyebilir (WHO 2020e). Bu bakımdan eldiven kullanımı bireylerin her yere rahatça dokunabilmesine (virüsün eline bulaşmayacağ 1 hissi ile) ve sik sık eldivenin değiştirilmesi gerçeğinin unutulup virüsün bulaştırıcılığının daha da artmasına neden olabilir.

\subsection{COVID-19 Virüsünün Belirtileri}

COVID-19 virüsüne bağlı enfeksiyon hastalığında ortaya çıkabilecek en yaygın belirtiler son 14 gün içinde ortaya çıkan ateş, kuru öksürük, dispne, myalji ve yorgunluk olup daha az sıklıkta görülebilecek belirtilerin ise baş ağrısı, balgam, hemoptizi, diyare, tat ve koku almada değişiklik, 
titreme, bulant1, kusma, burun tıkanıklığı gibi belirtiler olduğu görülmektedir (Gattinoni ve ark., 2020; Huang ve ark., 2020).

COVID-19 hastalarının \%80'inde hafif semptomlar ortaya çıkarken, \%20'sinde ise ciddi hastalık semptomları görülmektedir. Ciddi hastalık semptomları gösteren bireylerde pnömoni, ağır solunum yolu enfeksiyonu, çoklu organ yetmezlikleri gelişmekte ve hatta hastalık ölümle sonuçlanmaktadır. Özellikle 60 yaş üzerinde olan ve beraberinde hipertansiyon, kardiyovasküler hastalık, kronik akciğer hastalığ hastalığ 1 gibi kronik bir ya da daha fazla hastalı̆̆ 1 olan bireylerde hastalık daha ağır seyretmektedir (T.C Sağlık Bakanlığı Halk Sağlığı Genel Müdürlüğü 2020a).

\subsection{COVID-19 Virüsünden Korunma Yolları}

Korona virüse karşı geliştirilmiş bir aşı olmadığ için hastalıktan korunmadaki en etkili yol virüse yakalanmamaktır (CDC 2020a). Mevcut bilgiler 1şı̆̆ında SARS-CoV-2 virüsünün iklimden etkilendiği, ultraviyole (UV) radyasyonun virüsü yok edebileceği, burnun ve boğazın tuzlu su ve sirke ile yıkanmasının virüsü öldürebileceği, sarımsağın antimikrobiyal olması gerekçesiyle tüketilmesinin hastalıktan koruyabileceğine dair kanıtlanmış bir bilgi yoktur (WHO 2020f). Bağışıklık sistemini güçlendirmek ve hastalıktan korunmada alınabilecek en etkili önlem olduğu için dikkat edilmesi gerekenlerin başında dengeli beslenmek, fiziksel aktivite yapmak, yeterli oranda istirahat etmek ve düzenli uyumak gelmektedir (Sun ve ark., 2020).

Bir diğer önemli korunma yöntemi de sosyal mesafeyi korumaktır (WHO 2020g). Korona virüs damlacık yolu ile 1-2 metre uzağa kadar yayılabildiğinden bu mesafenin bireyin günlük yaşamında bir alışkanlığa dönüştürülmesi ve toplum içerisinde de bireylerle yakın temastan kaçınılması önem arz etmektedir (CDC 2020a). Mümkün olduğunca kalabalık ve toplu bulunulan alanlardan uzak durulmalı ve gerekmedikçe seyahat edilmemelidir (UpToDate 2020).

Dikkat edilmesi gereken diğer nokta ise bireylerin yaşam alanlarında sıkça temas ettikleri yüzeylerin düzenli olarak temizlenmesi ve dezenfekte edilmesidir. Bu doğrultuda kapı kolları, masalar, aydınlatma düğmeleri, kumandalar ve daha birçok dokunulan alanların temizliğine özen gösterilmesi gerekmektedir. $\mathrm{Bu}$ alanların temizliğinde alkol oranı en az \% 70 olan solüsyonlar kullanılabileceği gibi sulandırılmıș çamaşır suları da (oda sıcaklığında bulunan 5 yemek kaşığı suya
\%5,25-8,25 çamaşır suyu veya 4 çay kașı̆̆ 1 oda sıcaklığındaki suyun dörtte biri başına \%5,25-8,25 çamaşır suyu) kullanılabilmektedir (CDC 2020a). Yaşam alanları da sik sik havalandırılmalıdır. Korunmada çevre temizliğine de önem verilmeli, toplu kullanım alanı olan ulaşım araçları sık sık havalandırılarak ortak kullanılan yüzeyler de sık sık dezenfekte edilmelidir (CDC 2020c).

Gerek ülkemizde gerekse de Dünya'da sosyal izolasyona yönelik; kalabalık ortam oluşturacak toplantı ve etkinliklerin ertelenmesi, iş yerinden ziyade evde çalışmaya yönelik uygulamaya geçilmesi, okulların kapatılarak eğitimin okul dışında ve evde uzaktan eğitimle devamı vb. şeklinde önlemler alınmıştır (ECDC 2020). Özellikle bu süreçten önce ve bu süreçte hastalığın görüldüğü ülkelere seyahat eden bireylerin kendi ülkelerine döndükten sonra 14 gün boyunca evde kendilerini izolasyona almaları ve hastalığa ait semptomların ortaya çıkması ile de maske takarak mutlaka en yakın sağlık kuruluşuna başvurmaları gerekmektedir (T.C Sağlık Bakanlığı Halk Sağlığı Genel Müdürlüğü 2020a). Maske takmak virüsün başka insanlara yayılımını sınırlandırmasına rağmen tek başına yeterli bir önlem de değildir (WHO 2020h).

Tam bir koruyuculuk için maske takılmalı, el hijyenine uyulmalı, sosyal izolasyona ve diğer önlemlere dikkat edilmelidir. Eğer yaşanılan alanda COVID-19 tanısı almış bir birey varsa mutlaka onu ayrı bir odaya izole edip, ayrı odalarda farklı yaşam alanları olușturulmalı, mutlaka maske takılmalı, hijyen şartları ve temizlik kurallarına uyulmalıdır (CDC 2020a). Maskelerin tek kullanımlık olduğu unutulmamalı ve nemlendiğinde mutlaka maskeler değiştirilmelidir (WHO 2020k). Nemlenen, kirlenen ve hasar gören maske koruyuculuk sağlamamakta olup, yeni maske takılmadan önce el hijyeninin yapılması gerektiği unutulmamalıdır (WHO 2020h). Bunlara ilaveten korona virüs hastas1 olan bireyin çamaşırları 60-90 C derece sıcaklıkta ve ayrı olarak yıkanmalıdır (T.C Sağlık Bakanlığı Halk Sağlığ Genel Müdürlüğü 2020c).

\section{COVID-19 Virüsü ve Yașlı Bireylerin}

\section{Durumu}

Yaşlanma intrauterin dönemde başlayan ve yaşamın sonuna kadar devam eden bir süreç olup; anatomik yap1, biyolojik ve fiziksel işlev değişiklikleri ile birlikte duygusal ve sosyal değişimlerin yaşandığ 1 bir süreçtir. $\mathrm{Bu}$ sürecin içinde yaşlılığın başlangıcı 65 yaş olarak kabul edilmektedir (Sayın 2012). Yaşlılık aynı zamanda üretkenliğin azaldığı, kişilerarası ilişkilerin 
zayıfladığı ve sağlığın bozulması gibi birçok sorunun da beraberinde yaşandığ 1 bir dönemdir (Şener 2018). Doğum sayısı ve doğurganlığın azalması, yaşamdan beklentinin artması, tıptaki gelişmeler, ortalama insan ömrünün uzaması yaşlı nüfusun toplam nüfus içindeki oranını artırmıştır (Korkmaz Aslan 2017). Türkiye İstatistik Kurumu (TÜİK) 2019 yılı verilerine göre 65 yaş ve üzeri nüfus oranının \%9.1'e ulaştığ nüfusun 2023 'de \%10.2'ye, 2040'da ise \%16.3'e ve 2080 'de ise \%25,6'ya yükselmesi öngörülmektedir (Çalkaya ve Gökkoyun, 2020).

Dünya Sağl1k Örgütü tarafından 3 Mart 2020 de yapılan açıklamada COVID-19 pandemisi nedeniyle ölüm oranının $\% 3,4$ olduğu, ölümlerin $2 / 3$ 'sinin erkeklerde, 1/3'inin ise kadınlarda görüldüğü ve ölümlerin \%80'inden fazlasının 60 yaş üstünde ortaya çıtı̆̆ $1, \% 75$ 'inin ise hipertansiyon, kardiyovasküler hastalık, kronik akciğer hastalığ1, diyabet ve kanser başta olmak üzere diğer immunsüpresif durumlara sahip bireyler olduğu görülmüştür (WHO 20201). DSÖ’nün açıkladığı COVID-19 raporuna göre ölümlerin çoğunlukla ileri yaştaki bireylerde ve buna ek olarak hipertansiyon, kronik akciğer hastalığı, kardiyovasküler hastalıklar, diyabet, kanser, immunsüpresif durumlar başta olmak üzere bunun gibi eşlik eden sistemik hastalığı olan bireylerde ortaya çıtı̆̆ bildirilmiştir (WHO 2020b). COVID-19 tanısı ile hastaneye yatırılan hastalarda hipertansiyon, diyabetes mellitus, kronik kalp hastalığı, böbrek hastalıkları, solunum sistemi hastalıkları, kanserler ve obezite gibi çeşitli komorbiditeler saptanmıştır. Hastalığın şiddetli olduğu ve mortalitenin en yüksek olduğu grup 60 yaş üstü ve kronik bir ya da daha fazla hastalığ olan bireylerdir (WHO 2020d). Sağlık Bakanlığı'nın Türkiye verilerine göre hastalığın daha çok 60 yaş ve üzerindeki kişileri etkilediği bildirilmiştir (T.C Sağlık Bakanlığ Halk Sağllğ 1 Genel Müdürlüğü 2020a). Washington Eyaletine ait birçok yaşlı bakım tesisinde yapılan bir araştırmada, 101 kişinin salgından etkilendiği, etkilenen tesis sakinlerinin ortalama yaşının 83 olduğu ve \%94'ünde altta yatan kronik bir hastalığın olduğu saptanmıştır (McMichael ve ark., 2020). Çin'de COVID-19 ile enfekte olan 46248 hastada yapılan 8 çalışmanın bir meta analiz sonucunda ise, hastaların bir komorbiditesinin bulunduğu bildirilmiştir (Yang ve ark., 2020).

Sağlık Bakanlığı ileri yaş ve eşlik eden hastalığı (kalp hastalıkları, astım, diyabet gibi) olanlarda virüsün hastalık oluşturma riskinin daha ağır olduğunu ve hastalığın yaklaşık olarak \%2 olguda ölümle sonuçlandığını ilan etmiştir (T.C Sağlık Bakanlığı Halk sağlığı Müdürlüğü 2020b). Yüksek mortalite oranına sahip olan İspanya ve Amerika Birleşik Devletleri'nde de mortalite oranları 65 yaş üstü hastalarda \%70-80 düzeyindedir. İngiltere'de COVID-19'lu hastalarda yapılan bir çalışmada ek komorbiditesi olan 60-79 yas arası bireyde görülen ölüm oran $1 \% 5.1$ iken 80 yaş üstünde $\% 9.3$ mortalite oranı saptanmıştır (Ferguson ve ark., 2020). COVID-19 hastası olan 1527 kişinin içinde olduğu altı çalışmalı bir meta analizde ise hipertansiyon, kardiyovasküler hastalık ve diyabetes mellitus sıklığ1 sirasılla \%17.1, \%16.4, \%9.7 olarak bildirilmiştir. $\mathrm{Bu}$ çalışmada yoğun bakım hizmeti almaya ihtiyaç duyan hastalarda ihtiyacı olmayanlara göre, kardiyovasküler hastalık görülme oranı daha fazla bulunmuştur (Li ve ark., 2020).

COVID-19 enfeksiyonunun akut dönemde solunum sistemini etkilediği bilinmektedir. Buna ek olarak solunum sistemi dișında kalp, dolaşım, müsküler, metabolik ve nörolojik sistemi de etkilemekte ve komorbid hastalıkların da olmasıyla ileri yaştaki hastalarda daha ağır seyretmektedir (T.C Sağlı Bakanlığı Halk Sağlığı Genel Müdürlügü 2020a).

Fizyolojik olarak kaçınılmaz bir olgu olan yaşlanma, yaşın ilerlemesiyle birlikte bireylerde fizyolojik ve psikososyal değişimlerin yaşandığı ve buna bağlı olarak yaşam kalitesinin de bozulduğu bir dönemdir (Bilir ve Paksoy Erbaydar, 2015). Evde yaşayan yaşlilarda yaşam kalitesinin incelendiği bir çalışmada kronik hastalıkların varlığ ve depresif semptomlarının olmasının, yaşlıların yaşam kalitesini olumsuz yönde etkilediği bildirilmiştir (Altuğ ve ark, 2009).

Yaşlılıktaki fizyolojik değişikliklerden en fazla etkilenen sistem kardiyovasküler sistem olup, bu sistemde ortaya çıkan kas ve ileti sistemindeki hücre kayıpları, yaşl11ıktaki mortalite ve morbiditeyi etkileyen en önemli sistemdir. Yaşa ve genetik faktörlere bağlı olarak da kan pompalama yeteneğindeki azalma, kalp kapaklarında ortaya çıkan değişikliklere bağlı olarak bireylerde hipertansiyon, kalp yetmezliği, kroner arter hastalıkları, trombüsler ve kapak hastalıkları görülme riski artar (Aldemir ve Adalı, 2013; Priebe 2000). COVID-19 miyokard hasarına neden olup, var olan bu durumların alevlenmesine, akut ve kronik komplikasyonların ortaya çıkmasına sebebiyet verebilir.

Yaşlanma ile vücutta önemli değişikliklerin görüldügü sistemlerden biri de solunum sistemi ve bu sistemin en hayati organı olan akciğerlerdir. 
Yaşın ilerlemesine bağlı olarak solunum kasları zayıflar, solunum sisteminde görevli olan organlarda değişimler ortaya çıkar ve gribal enfeksiyonlar, pnömoni, tüberküloz, astım, koah, akciğer kanseri gibi solunum sistemi hastalıkları gelişir (Aslan 2019; Özkayar ve Arığul, 2007). COVID-19 bir solunum sistemi hastalığ1 olduğundan, ortaya çıkan bu değişikliklerle birlikte yaşlıların bu enfeksiyonla daha kolay karşılaşması ve yaşlılarda bu hastalığın daha ağır geçmesi kaçınılmaz olabilir.

İmmün sistem yaş, genetik faktörler, beslenme durumu, sigara içme alışkanlığ düzeyi, alkol tüketimi, enfeksiyonlar, stres, hormonlar, aş1 öyküsü gibi birçok faktör tarafından etkilenir. $\mathrm{Bu}$ faktörler arasında immün sistemi güçlendiren en önemli belirleyici dengeli beslenmedir (TÜBA 2020). Yaşın ilerlemesine bağl1 olarak immün sistem baskılanıp, enfeksiyonlara karşı hassasiyet artmakta ve yaşlı bireylerde enfeksiyonlar daha ciddi seyretmektedir (Soyuer ve Soyuer, 2008). Yaşlı bireylerdeki kronik ve komorbid hastalıkların varlığı da yaşlı bireylerde enfeksiyon hastalıklarının görülme sıklığını artırmaktadır (Karadakovan 2014). Görülmektedir ki kardiyovasküler, solunum ve immün sistemdeki değişiklikler ile bağışıklık sisteminin fonksiyonunda azalmanın ortaya çıkması, yaşılıların enfeksiyonlara karşı daha hassas olmasına ve enfeksiyon hastalıklarının yaşlılarda daha ciddi seyretmesine neden olabilir.

Yaşlı bireylerin bu dönemde hissettiği yalnızlık, bireylerin uyku kalitesinin düşmesine, fiziksel aktivitelerinin azalmasina, (Buchman ve ark., 2010; Hawkley ve ark., 2008), hastalık ve ölüm oranlarının artmasina (Luo ve ark., 2012) ve depresyona (Peerenboom ve ark., 2015) neden olmaktadir. Yalnızlıkta olduğu gibi sosyal izolasyonda da sağlıkla ilgili olumsuz durumlar gözlenmekte, hastalık ve ölüm oranlarındaki artış (Holt Lunstad 2010) ile birlikte bilişsel fonksiyonlarda bozulmalar ortaya çıkmaktadır (Barnes ve ark., 2004).

Yaşanan bu küresel salgın bireylerin hayatlarını fizyolojik olarak etkilemekle kalmayı aynı zamanda psikolojik etkiler de gösteren bireylere sıkıntı veren bir durumdur. $\mathrm{Bu}$ süreç bireylerde travmatik sonuçlar ortaya çıkarabilmekte fakat bireylerin yaşı, bireysel özellikleri, sınıfsal yapısı, kültürel durumu, dini inanc1, sosyo-ekonomik durumu, sosyal destek düzeyi ve ruhsal yapısı değişkenlik göstereceğinden bu sürecin yaşanmasında ve atlatılmasında bireylerde görülen travmatik etkilerde farklılıklar ortaya çıkabilmektedir. Bu süreçte yaşanan belirsizlikler, hastalığın kendisine ve ailesine bulaşacağı endişesi, yaşadığ1 yerin güvenilir olmadığ 1 düşüncesi, ne kadar süre bu durumun devam edeceği gibi değerlendirmeler bireylerde yoğun bir kayg1 duygusunun yaşanmasına sebebiyet verecektir. Daha da önemlisi bu sorunların artış göstereceği dönem izolasyon ve karantina sürecidir (CSTS 2020; Türkiye Psikiyatri Derneği Ruhsal Travma ve Afet Çalışma Birimi 2020).

İzolasyon ve karantina süresince sevdiklerinden ayrı kalma, özgürlüğün kaybı, hastalığın kendisinde de ortaya çıkacağı endişesi, hastalığın seyri gibi konularda yaşanan belirsizlikler bireylerin ruhsal yapıs1 üzerinde dramatik etkiler yapabilir. Bireylerde buna bağlı stres, öfke sorunları, paralelinde davranış sorunları, iletişim güçlükleri, depresyon, anksiyete, uyum güçlükleri gibi sorunlar yaşanabilir. Karantina süresi uzadıkça, hastalık ve ölüm oranları arttıkça da bireylerin ruhsal durumu daha da kötüleșecektir (CSTS 2020; Türkiye Psikiyatri Derneği Ruhsal Travma ve Afet Çalışma Birimi 2020). Yapılan bir çalışma COVID-19 pandemisinin kronik hastalığ olan ve sağlı durumu iyi olmayan bireylerde stres, anksiyete ve depresyonu artırdığı saptanmıştır (Wang ve ark., 2020).

Yaşlı bireylerde COVID-19'a ait görülebilecek en yaygın belirti ateş olmasına rağmen bu belirti immün sistemi zayıflamış ve kaşektik bireylerde fark edilemeyebilir. Bu belirtiye ek olarak, öksürük ve nefes darlığı, hareket bozukluğu ve fonksiyon kaybı ortaya çıkabilir. Demans ve Alzheimer'ı olan yaşl1 COVID-19 hastalarında semptom değerlendirmesi ve izolasyon stratejilerinde zorluklar yaşanabileceği unutulmamalıdır. Hastanelerde COVID-19 nedeniyle takip edilen 65 yaş ve üzeri hastalardaki tedavi protokolü ile genç hastalardaki tedavi protokolü aynı olmasına rağmen özellikle yoğun bakım ünitelerinde tedavi altına alınan ve mekanik ventilasyon uygulanan hastalarda venöz tromboemboli, katetere bağlı ortaya çıkan enfeksiyonlar, dekübit (bası) ülserleri ve deliryum insidans1 gibi komplikasyonların görülme oranı yüksektir (CDC 2020d; WHO 2020h).

\section{Sonuç ve Öneriler}

Türkiye'de yaşanan gelişmeler ve COVID-19 ile ilgili yaşanan belirsizlikler neticesinde, dünya genelinde özellikle 65 yaş ve üstünde ortaya çıkan vakaların ölümle sonuçlanması paniğe neden olup, yaşlıyı toplumda odak noktası yapmıştır. Bireylerin ve özelliklede en riskli grup olan, morbidite ve mortalite oranının en yüksek görüldüğü yaşlıları, 
diğer ülkelerde olduğu gibi Türkiye'de de virüsten korumak amaciyla gerekli tedbirler alınmalı, özellikle el hijyeni, sosyal mesafe ve maske kullanımının önemi anlatılıp bu süreçten fiziksel ve ruhsal olarak en az etkilenmeleri için,

$>\mathrm{Bu}$ sürecin yaşlı bireylerin yaşamında travmalara neden olması engellenip (yanlış bilgilenmeyi ve paniği önlemek amaciyla ekran maruziyeti önlenmeli ve psikolojik destek sağlanmalı), yaşamını iyi ve kaliteli bir şekilde sürdürmesi için bireylere olanaklar sağlanmalıdır.

$>$ Bireylerde bu süreç ile ilgili farkındalık oluşturulmalı ve kendi kendine önlem alması gerektiği anlatılmalıdır.

> Yaşlı bireylerin özellikle ruhsal rahatsızlıklardan korunmaları amacıyla yakınları ile sağlıklı bir iletişim ortamı oluşturulmalıdır.

$>\mathrm{Bu}$ süreçte hastalıklardan korunmada ve salgınlarla mücadeledeki en önemli adımın yanlış, güvenilir olmayan bilgilere itibar edilmemesidir. $\mathrm{Bu}$ durum özellikle de yaşlilarda gereksiz endişe yaşanmasına sebebiyet verebileceğinden, bu konuda en doğru bilginin konuya hakim alanında uzman olan kişiler tarafından verileceği ve hastalıklara karşı alınması ve uygulanması gereken en doğru önlemlerin uygulanmasının da gerekliliği göz önünde bulundurulmalıdır.

Her ne kadar 65 yaş ve üzeri nüfus için sokağa çıkma yasağı getirilse de onların da bu durumdan muaf tutulmadan günün belirli saatlerini, korunma ilkelerine dikkat ederek dişarda geçirmeleri sağlanmalıdır.

$>$ Haftalık ya da aylık sinırlı sayıda da olsa gerekli ve acil durumlarda kullanmak üzere maske kullanımı sağlamak amacıyla dağıtımın sürekliliği sağlanmalıdır.

> Yaşlı bireylerin bu virüsten korunması için sosyal izolasyona uymasının önemi anlatılmalıdır.

> Yaşanılan alanların temizlenerek dezenfekte edilmesi ve sık sık havalandırılmasının bu süreçte önemli olduğu, ellerin sabun ve su kullanılarak yıkanması gerektiği yaşlı bireylere açıklanmalıdır.

> Evde takip edilmesi gereken COVID-19 hastası olan bir bireyle aynı evi paylaşan COVID19'un ağır seyretmesine neden olabilecek risk etkeni olan bireyler ve/veya aynı evde kalan 65 yaş ve üstü grup mümkün olduğunca aynı ortamlarda bulunmamalı ya da temas riski en aza indirilmelidir.

$>$ Yaşlı bireylerin dengeli ve düzenli beslenmesinin önemi açıklanmalıdır. Tuz, yağ ve kolesterol oranı düşük, lif, sebze-meyve ağırlıklı ve protein miktarı dengeli bir beslenme önerilmelidir.
Sigara ve alkol gibi zararlı alıșkanlıkları varsa bırakmasının gerekliliği ve önemi anlatılıp, bırakması için destek olunmalıdır.

$>\mathrm{Bu}$ süreçte izolasyon nedeniyle ortaya çıkan sosyal destek kaynaklarının eksikliği bireylerde anksiyeteye neden olacağından psikolojik olarak ta yaşlı bireylerin desteklenmeleri önerilmektedir.

$>$ Kronik hastalığı olan ve çoklu ilaç kullanan bireylerin önerilen ilaç tedavisinin sürdürülmesi sağlanmalı ve ilaçları düzenli almaları konusunda bilgilendirilmelidir.

$>\mathrm{Bu}$ süreçte yaşlı bireylere stres ile nasıl başa çıkacağ1 öğretilmeli, stresi nasıl kontrol altına alacağına dair aktivite ve öneriler sunulmalıdır.

> COVID-19 hastalığında alınması gereken önlemlerin basit uygulanabilir önlemler olduğu ve bunun uygulanmasının da gerekli olduğu yaşı bireylere anlatılmalıdır.

\section{Araştırmanın Etik Yönü/ Ethics Committee} Approval: Literatür taraması yapıldı, derlemede kullanılan kaynaklara atıf yapılıp ilgili bölümde gösterildi.

Hakem/Peer-review: Dış hakem değerlendirmesi.

Yazar Katkısi/Author Contributions: Fikir/kavram: MAȘ; Tasarım: MAȘ; Kaynak tarama: MAȘ; Makalenin Yazımı: MAŞ; Eleștirel inceleme: MAŞ.

Çıkar çatışması//Conflict of interest: Çalışmada herhangi bir çıkar çatışması söz konusu değildir.

Finansal Destek/Financial Disclosure: Herhangi bir finansal destek alınmamıştır.

\section{Calışma Literatüre Ne Kattı?}

- COVID-19 virüsü hakkında bilgi verilmiştir.

- COVID-19'un belirtileri ve korunma yolları hakkında açıklamalarda bulunulmuştur.

- Yaşlı bireylerin COVID-19 virüsüne karşı korunması gerektiği ve yaşlı bireylerin tedbirli olmasının önemine değinilmiştir.

\section{Kaynaklar}

Aldemir M, Adalı F, (2013). Yaşlılarda Kalp ve Dolaşım Sistemi Hastalıkları. Altındiş M, editör, Yaşlılarda Güncel Sağlık Sorunları ve Bakım. İstanbul, İstanbul Tip Kitapevi, s. 116-122.

Altuğ F, Yağcı N, Kitiș A, Büker N, Cavlak U. (2009). Evde yaşayan yaşlılarda yaşam kalitesini etkileyen faktörlerin incelenmesi. Yaşlı Sorunları Araştırma Dergisi, (1), 48-60.

Aslan S. (2019). Yaşlanmada Meydana Gelen Fizyolojik, Psikolojik ve Sosyolojik Değişiklikler, Aylaz R, editör. Yaşlı Sağlığı ve Hemşirelik Bakımı. Malatya, İnönü Üniversitesi Yayınları: 49, s. 65-85. 
Barnes LL, Mendes de Leon CF, Wilson RS, Bienias JL, Evans DA. (2004). Social resources and cognitive decline in a population of older African Americans and whites. Neurology, 63(12), 2322-2326. DOI:https://doi.org/10.1212/01.WNL.0000147473.0 4043.B3.

Bilir N, Paksoy Erbaydar N. (2015). Yaşlılık Sorunları ve Bulaşıcı Olmayan Hastalıkların Kontrolü. Güler Ç, Akın L, editör. Halk Sağlığı Temel Bilgiler 3. Ankara, Hacettepe Üniversitesi Yayınları, s. 1528-1556.

Buchman AS, Boyle PA, Wilson RS, James BD, Leurgans SE, Arnold SE ve ark. (2010). Loneliness and the rate of motor decline in old age: the Rush Memory and Aging Project, a community-based cohort study. BMC Geriatrics, 10(1), 77, 1-8. DOI: 10.1186/1471-2318-10-77.

Centers for Disease Control and Prevention (2020a). Coronavirus Disease 2019 (COVID-19) How to Protect Yourself. 18 Mart 2020. Erişim tarihi: 21.03.2020, https://www.cdc.gov/coronavirus/2019ncov/prepare/prevention.html.

Centers for Disease Control and Prevention (2020b). Environmental Cleaning and Disinfection Recommendations. 6 Mart 2020. Erișim tarihi: 20.03.2020

https://www.cdc.gov/coronavirus/2019ncov/commun ity/organizations/cleaningdisinfection.html.

Centers for Disease Control and Prevention (2020c). What every American and community can do now to decrease the spread of the coronavirus. Erişim tarihi: 21.03.2020, https://www.cdc.gov/coronavirus/2019ncov/downloads/workplace-school-andhomeguidance.pdf

Centers for Disease Control and Prevention (2020d). 2019-nCoV: Prevention \& Treatment. Erişim tarihi: 12.04.2020, https://www.cdc.gov/coronavirus/2019ncov/about/prevention-treatment.html.

Center for the Study of Traumatic Stress (2020). Psychological Effects of Quarantine During the Coronavirus Outbreak: What Healthcare Providers Need to Know. Erișim tarihi:19.04.2020, https://www.cstsonline.org/assets/media/documents/ CSTS_FS_Psychological_Effects_Quarantine_Durin g_Coronavirus_Outbreak_Providers.pdf.

Çalkaya M, Gökkoyun SC. (2020). Türkiye'de yaşlı nüfus 5 yılda yüzde 21,9 arttı. Erişim tarihi: 20.04.2020, https://www.aa.com.tr/tr/turkiye/turkiyede-yaslinufus-5-yilda-yuzde-21-9-artti/1770051.

European Centre for Disease Prevention and Control. (2020). Novel coronavirus disease 2019 (COVID-19) pandemic: increased transmission in the EU/EEA and the UK - sixth update. ECDC. 12 Mart 2020. Erişim tarihi:

31.03 .2020

https://www.ecdc.europa.eu/sites/default/files/docum ents/RRA-sixth-update-Outbreak-ofnovelcoronavirus-disease-2019-COVID-19.pdf.
Ferguson NM, Laydon D, Nedjati-Gilani G, Imai N, Ainslie K, Baguelin M. ve ark. (2020). Impact of nonpharmaceutical interventions (NPIs) to reduce COVID-19 mortality and healthcare demand. London. Imperial College of London COVID-19 Response Team, 1-20,

DOI: https://doi.org/10.25561/77482.

Gattinoni L, Coppola S, Cressoni M, Busana M, Rossi S, Chiumello D. (2020). COVID-19 does not lead to a "typical" acute respiratory distress syndrome. American Journal of Respiratory and Critical Care Medicine. $201 \quad$ (10), 1299-1300. DOI:10.1164/rccm.202003-0817LE

Hawkley LC, Hughes ME, Waite LJ, Masi CM, Thisted RA, Cacioppo JT. (2008). From social structural factors to perceptions of relationship quality and loneliness: the chicago health aging, and social relations study. The Journals of Gerontological Series B: Psychological Sciences and Social Sciences, 63(6), 375-S384. DOI: 10.1093/geronb/63.6.s375.

Holt Lunstad J, Smith TB, Layton JB. (2010). Social relationships and mortality risk: a meta-analytic review. PLoS Medicine, 7(7), 1-20. e1000316. DOI: 10.1371/journal.pmed.1000316.

Huang C, Wang Y, Li X, Ren L, Zhao J, Hu Y ve ark. (2020). Clinical features of patients infected with 2019 novel coronavirus in Wuhan, China. Lancet, 395(10223), 497-506.

Karadakovan A. (2014). Yaşlılarda Önemli Sağlık Sorunları ve Bakım. Yaşı Sağlığı ve Bakım. Ankara, Akademisyen Kitapevi, s.300-305.

Korkmaz Aslan G. (2017). Yaşlı Sağlığının Geliștirilmesi. Ayaz Alkaya S, editör. Sağlığın Geliștirilmesi. Ankara: Hedef CS Basın Yayın, s. 284286.

Li B, Yang J, Zhao F, Zhi L, Wang X, Liu L ve ark. (2020). Prevalence and impact of cardiovascular metabolic diseases on COVID-19 in China. Clinical Research Cardiology, 109, 531-538.

Luo Y, Hawkley LC, Waite LJ, Cacioppo JT. (2012). Loneliness, health, and mortality in old age: a national longitudinal study. Social Science and Medicine, 74(6), 907-914.

DOI:10.1016/j.socscimed.2011.11.028.

McMichael TM, Currie DW, Clark S, Pogosjans S, Kay M, Schwartz NG ve ark. (2020). Epidemiology of Covid-19 in a Long-Term Care Facility in King County, Washington. The New England Journal of Medicine. 382. 1-7. DOI: 10.1056/NEJMoa2005412.

Özkayar N, Arıoğul S. (2007). Yaşlanma ile Meydana Gelen Fizyolojik Değişiklikler. İç Hastalıkları Dergisi, 14(1), 18-26. 
Peerenboom L, Collard RM, Naarding P, Comijs HC. (2015). The association between depression and emotional and social loneliness in older persons and the influence of social support, cognitive functioning and personality: A cross-sectional study. Journal of Affective Disorders, 182, 26-31. DOI: 10.1016/j.jad.2015.04.033.

Priebe HJ. (2000). The aged cardiovasculer risk patient. British Journal of Anaesthesia, 85(5), 763-78.

Rothe C, Schunk M, Sothmann P, Bretzel G, Froeschl G, Wallrauch C ve ark. (2020). Transmission of 2019. nCoV Infection from an Asymptomatic Contact in Germany. The New England Journal of Medicine, 382(10), 970-971.

Sayın, Y. (2012). Yaşlılık Süreci ve Etkileri. Durna Z. editör. Kronik Hastalıklar ve Bakım. İstanbul: Nobel Tip Kitabevleri, s. 517-537.

Soyuer F, Soyuer A. (2008). Yaşl1lık ve fiziksel aktivite. İnönü Üniversitesi Tıp Fakültesi Dergisi, 15 (3), 219 224.

Sun P, Lu X, Xu C, Sun W, Pan B. (2020). Understanding of COVID-19 based on current evidence. Journal of Medical Virology. 92, 548-551.

Şener, A. (2018). Yaşlılık, Yaşam Doyumu ve Boş Zaman Faaliyetleri. Erişim tarihi: 10.11.2018, http://www.sdergi.hacettepe.edu.tr/yasamdoyumu.pd f.

T.C. Sağlık Bakanlığı (2020a). Halk Sağlığı Genel Müdürlüğü, COVID-19 (Yeni Koronavirüs Hastalığı) Nedir?. Erişim tarihi: 21.07.2020, https://covid19bilgi.saglik.gov.tr/tr/covid-19-yenikoronavirus-hastaligi-nedir.html.

T.C. Sağlık Bakanlığı (2020b). Halk Sağlığ Genel Müdürlüğü, COVID-19 (Yeni Koronavirüs Hastalığı), COVID-19 Halka Yönelik Sıkça Sorulan Sorular. Erişim tarihi: 21.07.2020, https://covid19bilgi.saglik.gov.tr/tr/sss/halkayonelik.html.

T.C. Sağlık Bakanlığı (2020c). Halk Sağlığı Genel Müdürlüğü, COVID-19 (Yeni Koronavirüs Hastalığı), COVID-19 Rehberi, COVID-19 (SarsCov-2 Enfeksiyonu), Temaslı Takibi, Salgın Yönetimi, Evde Hasta İzlemi ve Filyasyon. Erişim tarihi:

21.07.2020

https://covid19bilgi.saglik.gov.tr/depo/rehberler/covi d-19-rehberi/COVID-

19_REHBERI_TEMASLI_TAKIBI_EVDE_HAST

A_IZLEMI_VE_FILYASYON.pdf

Til A. (2020). Yeni koronavirüs hastalığ (COVID-19) hakkında bilinmesi gerekenler. Göller Bölgesi Aylık Ekonomi ve Kültür Dergisi Ayrıntı, 8(85), 53-57.

Türkiye Bilimler Akademisi (TÜBA). 2020. COVID-19 Pandemi Değerlendirme Raporu, 17 Nisan 2020. Ankara. Erişim tarihi: 10.04.2020, http://www.tuba.gov.tr/files/images/2020/kovidrapor u/Covid-19\%20Raporu-Final+.pdf.

Türkiye Psikiyatri Derneği Ruhsal Travma ve Afet Çalışma Birimi. Karantinanın ruhsal etkileri ve koruyucu önlemler. Erișim tarihi: 19.04.2020, https://www.psikiyatri.org.tr/TPDData/Uploads/files/ KarantinaCOVID.pdf.

UpToDate (2020). Patient education: Coronavirus disease 2019 (COVID-19) (The Basics). 18 Mart 2020. Erişim tarihi: 01.04.2020, https://www.uptodate.com/contents/126678\#H17876 10950

Wang C, Pan R, Wan X, Tan Y, Xu L, Ho CS ve ark., (2020). Immediate psychological responses and associated factors during the initial stage of the 2019 coronavirus disease (COVID-19) epidemic among the general population in China. International Journal of Environmental Research Public Health, 17(5):1729.

World Health Organization (2020a). Statement on the second meeting of the International Health Regulations (2005) Emergency Committee regarding the outbreak of novel Coronavirus (2019-nCoV). Erişim tarihi: 03.05.2020, https://www.who.int/newsroom/detail/30-01-2020-statement-on-the-secondmeeting-of-the-international-health-regulations(2005)-emergency-committee-regarding-theoutbreak-of-novel-Coronavirus-(2019-ncov)

World Health Organization (2020b). Novel coronavirus (2019-nCoV). Situation Report 51. Erișim tarihi: 03.04.2020,

https://www.who.int/dg/speeches/detail/whodirector-general-s-open-ing-remarks-at-the-mediabriefing-on-covid-19---11-March-2020.

World Health Organization (2020c). Novel coronavirus (2019-nCoV). Situation Report 11. 31 January 2020. Erişim tarihi: 01.04.2020, https://www.who.int/docs/defaultsource/coronaviruse/situation-re-ports/20200131sitrep-11ncov.pdf?sfvrsn=de7c0f7_4.

World Health Organization (2020d). Clinical management of severe acute respiratory infection (SARI) when COVID-19 disease is suspected. Interim Guidance. Erişim Tarihi: 12.04.2020, WHO Reference number WHO/2019-nCoV/clinical/2020.4.

World Health Organization (2020e). Coronavirus disease (COVID-19) advice for the public. 18 Mart 2020. Erişim tarihi: 10.04.2020, https://www.who.int/emergencies/diseases/novelcoronavirus-2019/advice-for-public.

World Health Organization (2020f). Coronavirus disease (COVID-19) advice for the public: Myth busters. Erişim tarihi: 01.04.2020, https://www.who.int/emergencies/diseases/novelcoronavirus-2019/advice-for public/mythbusters.

World Health Organization (2020g). Rational use of personal protective equipment (PPE) for coronavirus disease (COVID-19). 19 Mart 2020. Erişim tarihi: 01.04.2020, https://apps.who.int/iris/bitstream/handle/10665/331 498/WHO-2019-nCoV-IPCPPE_use-2020.2-eng.pdf. 
World Health Organization (2020h). Advice on the use of masks in the community, during home care and in healthcare settings in the context of the novel coronavirus (COVID-19) outbreak. 19 Mart 2020. Erişim tarihi: 31.03.2020, https://www.who.int/publications-detail/advice-onthe-use-of-masks-in-the-communityduring-homecare-and-in-healthcare-settings-in-the-context-of-thenovel-coronavirus-(2019-ncov)-outbreak.

World Health Organization (2020k). Coronavirus disease (COVID-19) advice for the public: When and how to use masks. 2020. Erişim tarihi: 21.03.2020, https://www.who.int/emergencies/diseases/novelcoronavirus-2019/advice-for-public/whenand-howto-use-masks.

World Health Organization (20201). 3.4\% Mortality Rate estimate by the World Health Organization (WHO) as of March 3 (2020). Erişim tarihi: 05.04.2020, https://www.worldometers.info/coronavirus/coronavi rus-death-rate/\#correct. Coronavirus: case fatality rates by age. https://ourworldindata. org/uploads/2020/03/COVID-CFR-by-age1536x1190.png.

Yang J, Zheng Y, Gou X, Pu K, Chen Z, Guo Q ve ark. (2020). Prevalence of comorbidities in the novel Wuhan coronavirus (COVID-19) infection: a systematic review and meta-analysis. International Journal of Infectious Diseases, 12; s:12019712(20)30136-3. DOI:10.1016/j.ijid.2020.03.017. 